\title{
LEGAL ASPECTS OF THE IMPLEMENTATION OF EUROPEAN UNION'S COMMON COMMERCIAL POLICY: LITHUANIAN EXPERIENCE AND PRACTICE
}

\author{
Gediminas Valantiejus ${ }^{1}$ \\ ${ }^{1}$ Mykolas Romeris University,Lithuania, gvalantiejus@mruni.eu
}

\begin{abstract}
The Common Commercial Policy is the essential basis of the European Union (hereinafter - the EU), which, in particular, is a free trade area between the 28 Member States with a common external customs tariff and a common foreign trade policy as well as common trade rules with the third countries. Implementation of this policy is characterized by the fact that it is based on an exclusive competence of the EU, which after the Treaty of Lisbon (2009) became even more apparent. Therefore the countries of the EU should follow the same legal principles and rules in the regulation of their foreign trade, that is to apply the uniform EU rules on the calculation of customs duties and determination of the customs origin of goods, customs valuation and tariff classification of goods (Common Customs Tariff). However, implementation of these provisions is always experiencing stress due to the different interests of the EU Member States and the different national practices, especially when the administration of customs duties is actually implemented only at the level of individual EU Member States. Therefore the aim of the article is to assess the implementation of the EU's CCP from the perspective of the EU Member State (Lithuania) and to describe existing discrepancies which may serve as an obstacle for the development of common regulatory regime for import customs duties in the EU or hinder its main economic goals in international trade. Analysis of relevant scientific problems is mainly based on the comparative method (comparison of the practice of the national courts in the Republic of Lithuania and the Court of Justice of the European Union in disputes related to the functioning of the EU's customs union) and generalization of professional experience (national and EU judicial practice). The research leads to the conclusion that a uniform implementation of Common Commercial Policy and the Common Customs Tariff, as its main element, is not fully ensured on the practical level from the perspective of certain Member States (i.e. Lithuania).
\end{abstract}

Keywords: international trade, customs law, EU's Common Commercial Policy, the Union Customs Code

Type of the paper: Empirical study

JEL Classification: F13 - Trade Policy: International Trade Organizations; K39 - Other: Customs Law

\section{Introduction}

Topicality of the research. International trade is an essential element for the economic growth, increasing employment and prosperity of each country's. This is important for both the European Union (hereinafter - EU) and its constituent 28 Member States. Since the establishment of the European Community, its founding treaties have provided the regulations, which were aimed to develop and implement a Common Commercial Policy (common foreign trade policy). This policy was and is seen as one of the most important in order to create the conditions for the functioning of the customs union and common market (Craig, de Burca 2011). Effective implementation of this policy not only helps to ensure the proper functioning of the single internal market in which the free movement of goods between the Member States is ensured, but also contribute to the achievement of fiscal targets as customs duties (import taxes) are one of the main foreign trade regulation measures and are attributed to the EU's own budgetary resources. Thus, the proper and uniform administration of the customs duties in the EU Member States is essential to the financial stability of the EU. Since 1 May 2004, Lithuanian Republic has also joined the EU and has started to implement its trade relations with third countries according to the requirements of the EU Common Commercial Policy, which 
means that foreign trade should be regulated and governed uniformly and unanimously, using common legal provisions and rules (Leal-Arcas 2008).

This implies the existence of unified legal provisions and the rules governing the regimes of EU foreign trade with the third countries, which includes both the EU internal law (establishing a Common Customs Tariff of the EU), as well as bilateral and multilateral agreements with third countries. The aim of this legal regulations is to secure liberalization of the international trade and customs duties (Leal-Arcas 2011). As it is emphasized in scientific literature (Herdegen 2013; Lyons 2008), in this respect the mechanism of interaction between the EU and the Member States, is original - the one and only such formation in the world, as the legal system of the EU, regulating integration of international trade, is one of the responses of EU Member States to the challenges of globalization.

Accordingly, it should be noted that the Treaty of Lisbon, which has entered into force on 1 December 2009, has significantly increased the role of the EU in this area (see. Article 207 of Consolidated version of Treaty on the Functioning of the EU, 2012). According to the Treaty of Lisbon, all the aspects of Common Commercial Policy of the EU are included into the sphere of exclusive competence, and the institute of mixed agreements is applied only to the limited extent for the legal relations, related to the regulation of foreign trade in the EU and its Member States (Leal-Arcas, 2010). In this context and on the basis of insights, formulated in the legal doctrine, the main problematic aspects, affecting legal regulation of Common Commercial Policy after the Treaty of Lisbon, remains concentrated on the relationship between the EU law and national law, which regulates various aspects of Common Commercial Policy, such as, for example, determination of customs duties and application of Common Customs Tariff. These problems, linking them with the emerging practices of national courts (taking the example of the practices, pursued in the Republic of Lithuania), are analyzed and discussed in other sections of this article.

The Aim of the Research is to assess the implementation of the Common Commercial Policy of the EU from the perspective of the EU Member State (Lithuania) and to describe existing discrepancies which may serve as an obstacle for the development of common regulatory regime for import customs duties in the EU or hinder its main economic goals in international trade.

Research Hypothesis: existing judicial practices in the Member States of the EU (i.e. Lithuania) doesn't match with the practice of the Court of Justice of the European Union on the application of the EU Common Commercial Policy rules related to the determination of customs origin of goods, customs valuation and tariff classification of goods.

Applied Research Methods: analysis of relevant scientific problems is based both on theoretical (analysis and synthesis, systematic, comparative) and, in particular, empirical methods (statistical analysis of data, analysis of documents, generalization of professional experience, - practice of the courts of Lithuanian Republic in disputes with customs authorities and practice of the Court of Justice of the European Union in judicial cases related to the implementation of Common Commercial Policy of the EU).

The Results of the Research. From the perspective of certain EU Member States (i.e. Lithuania), the uniform implementation of Common Commercial Policy is not fully ensured on the practical level. The research highlights that significant differences between national practices and practices for the application of relevant EU law, which is formed by the CJEU, were detected In order to solve these problems, it is necessary not only to improve merely the mechanism of interaction between national courts and the CJEU, but also to change the existing national legal regulations and to establish specific new rules in the national legislation EU law, that would be more specific and comply with the interpretations of the EU law provided by the CJEU. Solving of these problems may also include certain revisions on the EU level, such as the concretization of the provisions of the Union Customs Code (2013) (Art. 1, para. 1) on the determination of applicable law.

\section{Literature Review}

General Insights on the Common Commercial Policy of the EU (Common Customs Tariff.) The authors, examining the problems of legal regulation of international trade in the EU (e.g. Leal-Arcas 
2011), identifies certain regulatory concepts of unilateralism, bilateralism/regionalism, multilateralism/plurilateralism. From an EU perspective, based on the concept of unilateralism, the $\mathrm{EU}$, in its sole discretion (unilaterally), imposes the liberalization measures for international trade, which are covered by the Generalized System of Preferences (hereinafter - GSP). Based on the provisions of GSP, the EU does not apply customs duties to goods, imported from individual developing countries. The multilateral dimension of the Common Commercial Policy (hereinafter $\mathrm{CCP}$ ) includes the implementation of multilateral WTO agreements. The bilateral (regional) dimension of the CCP means that the EU, using the instruments of the CCP, develop economic and trade relations with the third countries through bilateral preferential agreements creating free-trade zones. Since 2009, the Treaty of Lisbon has increased the EU Parliament's role in this field, simplifying the EU's foreign trade policy, moving away from the concept of mixed international agreements, which belonged to the competence of both the Community (EU) and its Member States (Woolcook 2008) and limiting requirements to ratify these agreements in national parliaments; Devuyst 2011; Broberg, 2011). Currently, all major international trade agreements in the EU belong to its competence and must ratified by the Parliament of the EU and the Council (Radžiukynas 2011; Leal-Arcas 2011). At the same time it should be emphasized that in its jurisprudence the CJEU has pointed out (see cases International Fruit Company NV and others v Produktschap voor Groenten en Fruit, 1972, paras. 14-18; Douaneagent der NV Nederlandse Spoorwegen v Inspecteur der invoerrechten en Accijnzen, 1975, para. 16; SPI and SAMI v Amministrazione delle Finanze dello Stato, 1983, para. 19) that the EU has replaced the Member States and has taken over their obligations with regard to the GATT agreement and other major international treaties on the issues of customs duties (for example, Agreements on the tariff classification of goods, the establishment of the World Customs Organization (hereinafter - WCO) and etc.).

The main legal regulations, outlining the scope of the EU's CCP are set in the Treaty on the Functioning of the EU, that is in its Article 207. In accordance with the provisions of this Article in all of the EU Member States, the regulation of foreign trade and the related provisions of the customs law falls within the exclusive jurisdiction of the EU institutions (Eechaut 2011). Currently extensive customs law rules, related to the EU's trade with the third countries and its tariff regulation instruments (based on taxation using customs duties) are also set in the sources of the EU legislation, i.e. in the Union Customs Code (Regulation (EU) No 952/2013 of the European Parliament and of the Council, 2013; hereinafter - the Union Customs Code), which is directly, fully and universally applicable in all the EU Member States. It should be emphasized that these rules of customs law constitutes the main element of the Common Commercial Policy in the EU and traditionally includes such aspects as tariff classification of imported goods for customs purposes, determination of customs origin and customs value (Barnard 2010; Moussis 2015). On the other hand, as noted by the authors both at the national level in individual EU Member States (for example in Lithuania by Radžiukynas and Belzus (2008)), and at the EU level (Lyons 2008) different level of organization of the customs control and the differences in the national legal regulations (which de facto could be liberal or more restrictive) leads to the objective discrepancies in the actual implementation of customs law while applying customs clearance procedures to the imported and exported goods and controlling their classification, origin and value. As it is noted by Limbach (2015), this may distort the uniform implementation of CCP or even create an unfair competition between the Member States in order to increase customs tax revenues obtained by the Member States and thus hinder the functioning of the single internal market of the EU. For this reason, problems of the classification of goods for customs purposes, determination of customs origin and customs value in the Member States of the EU is seen as an extremely important to the development of the CCP and relevant EU law.

Tariff classification of goods. The rapid increase of international trade has led to unification and simplification of international nomenclature, used for the tariff classification of goods for customs purposes. The legal framework for this process was established by the international Harmonized Commodity Description and Coding System Convention (hereinafter - Harmonized System or HS convention), signed in Brussels on 14 June 1983. Each country, which has ratified the HS convention (Lithuania joined it on 1 January 1995), undertook the responsibility to comply with the basic classification rules for its application as well as obliged to take into account all the notes, regarding the interpretation of its certain sections, headings and subheadings and not to modify the content of its 
sections, their headings and subheadings (Law of the Republic of Lithuania on the ratification of Harmonized Commodity Description and Coding System Convention, 2003).

It should be emphasized that the HS Convention provides only a general rules on the creation of Harmonized System for the tariff classification of goods. Meanwhile, the multipurpose nomenclature of goods, where each position is encoded using the six-digit digital code, is further detailed and explained in the Harmonized System Explanatory Notes (hereinafter - HSENs), which were developed by the WCO. On the other hand, the attention is often drawn on the compatibility of HSENs with the EU law and, specifically, its accordance with the Combined Nomenclature of the EU, enshrined in Council Regulation No. 2658/87 on the tariff and statistical nomenclature and on the Common Customs Tariff 1987 and its subsequent amendments (Commission Regulation No. 1101/2014 on the tariff and statistical nomenclature and on the Common Customs Tariff, 2015). While the Combined Nomenclature of the EU was prepared on the basis of the Harmonized System, incorporating its rules into EU law, the research carried out by individual authors (Weerth 2008) shows that in practical terms, they don't coincide completely. This reveals two problems; firstly, what is the legal power of the HSENs in the process of classification of goods for customs purposes in the system of EU law? Secondly, is it possible to apply the HSENs directly in the national legal system of the EU Member States on the basis of provisions of the Article 1, para. 1 of Union Customs Code (2013)) as an international arrangements which provide different regulations than the customs rules of the EU?.

According to Einhorn (2012) and Lux (2007), the HSENs explanations are not legally binding and should be qualified as the so-called "soft law" sources of law. Nevertheless, the modern doctrine of international economic and customs law (Wolffgang, Kafeero 2010) recognizes that such legal sources may have a practical effect. The practical effect of the HSENs, for example, unfolds when they are applied by the World Trade Organization (WTO) in order to settle the trade disputes between states and to interpret their international obligations on trade in goods (Einhorn 2012) or by the judicial authorities in the EU in order to ensure the uniform application of EU customs law (Lux 2007) This means that the explanations provided in the HSENs has a specific legal significance to the individual states and the EU, which has joined the HS Convention (Wolffgang, Ovie 2008). However, this raises the practical question how to deal with the situations when the provisions of HSENs and the Combined Nomenclature of the EU do not correspond to each other.

Rules of origin. Other important international dimension, which is essential for the legal regulation of customs duties, is the legal institute of customs origin of goods. The legal basis of it is a special Annex of the World Trade Organization (hereinafter - WTO) Agreement that is Agreement on Rules of Origin. It contains general provisions for determining the customs origin of goods that is the state, which is considered the country of origin of goods for customs purposes. The types of customs duties - regular (conventional) or reduced or preferential, - which should be applicable to the imported goods are determined by this legal factor (Terra, Wattel 2012 Lux 2002). Based on the concept of origin, preferential measures provide for the granting of preferential tariff treatments to goods originating from certain countries, groups of countries or territories (a reduced duty or zero rates) (Jisoo 2015). In general, in order to prove certain customs origin in the EU, special origin certificates are required and are mainly used for preferential treatment purposes: certificate EUR.1, EUR.2, or Form A, invoice declaration (Terra, Wattel 2012). Consequently, the application of rules on customs origin of imported goods is considered to be an exception to the general rule of non-discrimination in international trade, as the application of such rules justifies certain discrimination of imported goods (Leal-Arcas 2011). However, rules for the determination of customs origin of goods in the EU law (for example, the Community Customs Code, Article 17 ("Preferential origin of goods)) are formulated quite abstractly. This circumstance essentially creates a complex legal administrative system for the determination of customs origin of imported goods, which further leads to the additional costs for importers (exporters) and adversely affects the development of international trade. This is also related to the fact that the rules on the proof of preferential customs origin are usually stricter, especially regulating customs origin of goods, the production of which has included the use of products, originating from the number of countries (Audet 2007). Thus, in this case, it is essential for the EU law to ensure the uniform determination of customs origin of goods in the Member States and, in this 
context, to provide uniform provisions on the distribution of the burden of proof between the importers and customs authorities.

Customs valuation of imported goods. In its practice the CJEU has ruled that the functioning of a customs union requires uniform determination of the value of goods imported from third countries so that the level of protection effected by the Common Customs Tariff is the same throughout the whole Community (cases Hauptzollamt Bremerhaven v Massey-Ferguson GmbH, 1973, and Kommanditgesellschaft in Firma Gebrüder Glunz v Hauptzollamt Hamburg-Waltershof, 1982).Therefore, it was an urgent and difficult task is to develop a reasonable system, which could be suitable for all goods (products), for each country, for each type of transactions and could be easily applied. The main customs valuation principles were set at the WTO level only in 1994 by the General Agreement on Tariff and Trade (hereinafter - GATT) and its Article VII. However, the most important document for customs valuation of goods is the Agreement on the Implementation of Article VII of the GATT 94. According to the Agreement on the Implementation of Article VII of the GATT 94 (Law of the Republic of Lithuania on the ratification of Agreement founding World Trade Organization and its Annexes, 2001), the transaction value should be used to the greatest extent possible in ascertaining the customs value of goods. This primary basis for the valuation of imported goods is defined as the price actually paid or payable for the goods when sold for export to the customs territory, subject to specific qualifications and adjustments (the same provisions are enshrined in the Article 70 of the Union Customs Code (2013). This means that the main standard rule applied for the customs valuation in the EU is that the customs value of imported goods should be considered as the transaction value, provided that provided that the sale or price is not subject to some condition or consideration for which a value cannot be determined with respect to the goods being valued (Terra, Wattel 2012, Lyons 2008). However, as it is noted by Lyons (2008) and Lux (2007), the WTO rules on customs valuation are transpositioned and incorporated literally or almost literally into Community legislation. Therefore, their direct effect in the system of EU law is usually denied, although a practical level, this raises a number of questions, which were explored by the CJEU.

\section{Methodology}

In order to examine practical problems of the implementation of the EU CCP (i.e. implementation of Common Customs Tariff and its traditional main elements (Barnard, 2010) - tariff classification of imported goods for customs purposes, determination of the customs origin of imported goods and their customs valuation ) (the so-called three " $\mathrm{C}$ " system which is applied for the calculation of customs duties (classification, customs origin and customs value; see Baronaite, 2010)). This research examines the case law of the national courts of the Republic of Lithuania, in particular, practice of the Supreme Administrative Court of Lithuania, as the highest national judicial authority in disputes with customs authorities. It is important to mention, that according to the Law on Tax Administration of the Republic of Lithuania (2004) and the Law on the Proceedings of the Administrative Cases (1999) in Lithuania the disputes with the customs authorities which arise due to additionally calculated import taxes and related sums (such as interests and financial penalties) are considered as tax disputes. They are addressed by applying a multi-stage process that includes both pre-trial (customs authorities, Commission on Tax Disputes under the Government of the Republic of Lithuania) and judicial (Vilnius regional administrative court, the Supreme Administrative Court of Lithuania) level of the proceeding. In any case, the highest authority, which is responsible for the formation of final and mandatory practice (judicial precedents) which binds other persons and public authorities in all cases of such kind is the Supreme Administrative Court of Lithuania (the Law on the Proceedings of the Administrative Cases (1999), Article 13). Therefore the study focuses only on the cases which were examined in the Supreme Administrative Court of Lithuania and on the legal problems of the taxation of goods, which were imported from the third countries to Lithuania and were subject to additional customs duties (respectively, later challenged in the court). In order to evaluate the practical functioning of the CCP and to compare national practices on the application of the CCP rules with the practice of the CJEU in the same types of cases, all the national administrative cases as well as the judicial cases of the CJEU, which were analyzed in this article were divided into three main subcategories (tariff classification, customs origin and customs value). 
A more detailed analysis of national case law was carried out using the LITEKO system (i.e. Information System of the Courts of Lithuania which is a public and official database accessible at the website $<$ http://liteko.teismai.lt/viesasprendimupaieska/detalipaieska.aspx?detali=2>. )The research was carried out according to the time limitations (yrs. 2010 - 2015), i.e. only the judicial cases, which were examined after the Treaty of Lisbon and its provisions on CCP has entered into force, were selected and studied. In order to systematize the research and to select the required cases which were examined during the described period of time, the relevant official case law classification categories ("Classificatory of the categories of judicial decisions in administrative cases") used by the Supreme Administrative Court of Lithuania were invoked (the study included particular cases related to customs activity, classification number 1.10.2 (Common Customs Tariff and tariff classification of goods), 1.10.3 (Customs valuation) and 1.10.4 (Customs origin).

During the reporting period, 23 cases related to the tariff classification of goods, 7 cases related to the determination of customs origin and 17 cases related to the determination of customs value were detected. From this sample, certain cases, which includes examples of case law on problematic issues of the CCP and Common Customs Tariff (identified in the chapter "Literature Review", such as application of the HSENs, distribution of the burden of proof for the determination of customs origin of goods and application of WTO rules on the customs valuation), were selected and compared with interpretations of the same EU rules, which were formulated in the practice of the CJEU. The exact results of the study (including references to the specific cases) are provided in the chapter "Results".

\section{Results}

Tariff Classification of Goods (Common Customs Tariff). Based on the analysis of literature, one of the main problems encountered in the process of uniform application of the Common Customs Tariff throughout the EU is the relationship between HSENs and EU law (Combined Nomenclature of the $\mathrm{EU}$ or $\mathrm{CN}$ ). From a practical point of view, it can be seen that often tariff classification descriptions of imported goods, which are the basis of the amount of payable customs duty, varies and are differently described in the Combined Nomenclature of the EU, as well as in the HSENs explanations, provided by the WCO. Accordingly, in practice such situations were examined by the CJEU and the analysis of the relevant judicial practice leads to the conclusion that the CJEU has formulated a set of basic rules, which deals with the collisions between the Combined Nomenclature and the HSENs. These general rules allow determining the proper tariff classification description, which should be followed in each particular case.

The general relationship between the Combined Nomenclature of the EU, introduced by Regulation No 2658/87, and the legal acts adopted by the WCO was described by the CJEU in the number of cases (see for example joined cases Dinter GmbH v Hauptzollamt Düsseldorf and Europol Frost-Food v Hauptzollamt Krefeld, C-522/07 and C-65/08, para. 32). Here the Court has stressed that the Council of the European Union has conferred upon the Commission, acting in cooperation with the customs experts of the Member States, broad discretion to define the subject-matter of tariff headings falling to be considered for the classification of particular goods. However, the Commission's power to adopt the measures mentioned in Article 9(1)(a) of Regulation No 2658/87, like the classification of the goods, does not authorize it to alter the subject-matter of the tariff headings which have been defined on the basis of the HS established by the HS convention whose scope the European Union has undertaken, under Article 3 thereof, not to modify (see, to that effect, judgment in case_Raytek GmbH and Fluke Europe BV v Commissioners for Her Majesty's Revenue and Customs, 2015). This position of the Court was essentially based on the fact that under the Article 3(1) of the HS Convention, each Contracting Party undertakes to ensure that its customs tariff and statistical nomenclatures will be in conformity with the HS, to use all the headings and subheadings of the HS without addition or modification, together with their related codes, and to follow the numerical sequence of that system. The same provision states that each Contracting Party must also undertake to apply the general rules for the interpretation of the HS (that is HSENs) and all the section, chapter and subheading notes of the HS, and not to modify their scope.

Therefore the CJEU has also ruled that the Commission, as an EU institution which is responsible for amending and updating the Combined Nomenclature is not auhorized to amend customs duty rates by 
modifying the descriptions of goods in the Combined Nomenclature entirely to its own discretion (Hewlett-Packard Europe BV v Inspecteur van de Belastingdienst/Douane West, kantoor Hoofddorp, 2013, para. 40). Accordingly, the Combined Nomenclature of the EU must be kept in line with the general provisions of the HSENs (Joined Cases C-288/09 British Sky Broadcasting Group plc v The Commissioners for Her Majesty's Revenue \& Customs and C-289/09 Pace plc v The Commissioners for Her Majesty's Revenue \& Customs, 2011 E.C.R. I-02851, para. 64) as, for example, the CJEU has stated that the EU's Explanatory Notes of the Combined Nomenclature were not intended to replace the WCO HSENs but only to supplement them (Case 11/79, J. Cleton en Co BV v Inspecteur des droits d'entrée et accises a Rotterdam, 1979, para. 12-13).

Nevertheless, the presence of two formally different (but at least theoretically compatible) sources of law, which are used for the tariff classification of goods creates a practical question - which source should be considered as primary and legal binding in a case of collisions or uncertainties on classification? As it is pointed out by Lyons (2008), the EC material does not emanate from an authority entrusted with ensuring uniformity in the harmonized system by the contracting parties to it. Therefore, it may be thought it is, to that extent, less authoritative than the material issued by the WCO. The long-standing and traditional answer of the CJEU to this problem is such, that as regards the HSENs (that is the source of law adopted by the WCO), they do not have legally binding force but at the same time are considered as an important means of ensuring the uniform application of the Common Customs Tariff and, as such, may be regarded as useful aids to its interpretation, i.e. for interpreting the scope of the various tariff headings in the Combined Nomenclature of the EU (see, inter alia, judgment in TNT Freight Management (Amsterdam) v Staatssecretaris van Financiën, 2012, para. 32; Data I/O v Hauptzollamt München, 2014, paragraph 33). This interpretatory effect of the HSENs was further explained in the already settled and numerous case law of the CJEU.

Firstly, the CJEU has explained the conditions when the HSENs may be set aside and not applied. It may happen in situations when the content of explanatory notes from the WCO is formally not in accordance with the provisions of the Combined Nomenclature and when it alters the meaning of its provisions. Consequently, in cases C-38/75 (Douneagent der NV Nederlandse Sooprwegen v Inspecteur der Invoerrechten en Accijinzen, 1975) and C-233/88 (Gijs van de Kolk-Douane Expediteur BV v Inspecteur der Invoerrechten en Accijinzen, 1990), the Court has said, that the provisions of the HSENs can be set aside if they appear to be incompatible with the wording of the heading of the Combined Nomenclature or goes manifestly beyond the discretion conferred on the WCO. A similar position was held in the more recent practice (case JVC France v Administration des douanes - Direction nationale du renseignement et des enquêtes douanières, 2008, para. 34). Here the CJEU has ruled that where it is apparent that the explanatory notes are contrary to the wording of the headings of the Combined Nomenclature and the section or chapter notes, the explanatory notes must be disregarded . Therefore, in order to apply the HSENs, the wording of these explanatory notes must be consistent with the provisions of the Combined Nomenclature and cannot alter their scope or their content (see, inter alia, judgment in cases Sunshine Deutschland Handelsgesellschaft v Hauptzollamt Kiel, 2007, para. 27, Duval v Hauptzollamt Frankfurt am Main, 2015. para. 24, Vario Tek v Hauptzollamt Düsseldorf, 2015, para. 22). In such situations the HSENs could be used as a general interpretation guidelines for tariff classification of goods by the CJEU and by the national courts even if the status of the HSENs currently is not directly regulated by the Community Customs Code (currently, since 1 May 2016 - by the Union Customs Code) (see case C-472/12 (Panasonic Italia SpA, Panasonic Marketing Europe GmbH, Scerni Logistics Srl v Agenzia delle Dogane di Milano, 2014, para. 46)).

However, what regards the direct effect of HSENs in the system of EU law (direct invokability of the HSENs provisions in cases related to tariff classification of goods), the CJEU has numerously pointed out that interpretations provided by the HSENs must be taken into account in case when there are no Community rules, which could be applied in order to resolve questions concerning the tariff classification (Medion AG v Hauptzollamt Duisburg and Canon Deutschland GmbH v Hauptzollamt Krefeld, 2006; Commissioners of Customs \& Excise v SmithKline Beecham plc, 2005; DFDS BV v Inspecteur der Belastingdienst - Douanedistrict Rotterdam, 2004; Fábrica de Queijo Eru Portuguesa $\mathrm{Ld}^{\mathrm{a}} \mathrm{v}$ Tribunal Técnico Aduaneiro de Segunda Instância, 2000). Therefore the HSENs is applied as an 
authoritative source of interpretation on tariff classification of goods where no relevant explanatory notes have been issued by the EU which could provide the necessary descriptions og goods. This trend of the judicial practice of the CJEU was already noticeable in a number of quite early cases, such as Deutche Bakels GmbH v Oberfinanzdirektion Munchen, 1970, para. 9-10; Gervais-Danone AG v Hauptzollamt Munchen-Schwanthalerstrasse, 1971, para. 5 and etc.). Hence, the HSENs provided by the WCO are an authoritative guide where there is no explanatory material from the EU.

Summarizing the arguments above, it can be stated that, according to the judicial practice of the CJEU, the EU's Combined Nomenclature must be aligned with the rules and provisions of the HSENs. However, in general terms, the practice of the CJEU doesn't treat the HSENs itself as belonging to the category of directly applicable sources of international law, which must be followed by the CJEU and the national courts of the EU Member States resolving the disputes concerning the tariff classification of goods and granting them priority over the EU law, i.e. Community Customs Code and the Combined Nomenclature of the EU (see case C-196/10 (Paderborner Brauerei Haus Cramer KG v Hauptzollamt Bielefeld, 2011, para. 32)). As the CJEU has stated in case C-267/13 (Nutricia NV v Staatssecretaris van Financiën, 2014, para. 27), the main legal nature of the HSENs currently is and remains explanatory: the HSENs can be invoked and directly applied only when there are no established EU rules.

In this context, attention must be drawn to the fact that the issues of application of the rules, enshrined in the HSENs has been resolved in the national courts of the Republic of Lithuania (the Supreme Administrative Court of Lithuania), but the case law has not yet formulated a clear conclusion on the legal significance and status of the HSENs. The analysis of the case law in the relevant period (yrs. 2010-2015) shows, that the Supreme Administrative Court of Lithuania usually indirectly lists the HSENs (as it was mentioned, they are prepared by the WCO on the basis of the International Harmonised Commodity Description and Coding System Convention) among other sources of law, which are applicable to the tariff classification of goods: "goods are classified according to the International Harmonised Commodity Description and Coding System Convention and the European Community customs legislation" (the Supreme Administrative Court of Lithuania, 31 January 2013 ruling of the panel of judges in the administrative case No. $A^{143}-71 / 2013,2013$; the Supreme Administrative Court of Lithuania 1 February 2011 ruling of the panel of judges in the administrative case No. $\left.\mathrm{A}^{143}-218 / 2011,2011\right)$. However, a more detail comparative analysis confirms that on the practical level the application of the HSENs doesn't correspond to the practice of the CJEU.

First of all, it should be noted that there are examples when some of the national institutions (such as the Commission on Tax Disputes under the Government of the Republic of Lithuania) apply the HSENs in order to classify goods directly. For example, in the administrative case No. A-442176/2010 the Commission on Tax Disputes under the Government of the Republic of Lithuania invoked the provisions of the HSENs in order to classify imported goods (food products from Atlantic salmon (Salmo Salar)) and to explain the certain position (0303, 0304 and 0511 of the Harmonized System) where the product has to be classified (the Supreme Administrative Court of Lithuania 28 January 2010 ruling of the panel of judges in the administrative case No. $A^{442}-176 / 2010,2010$ ). However, while checking the correctness of the decisions of such institutions in the relevant tax disputes, the Supreme Administrative Court of Lithuania usually refrains from applying the provisions of the HSENs and is justifying its final rulings (decisions) only on EU customs legislation, that is the Combined Nomenclature of the EU as the one and only main source governing the tariff classification of imported goods. Thus, even in cases where the applicant states that the descriptions of goods, used for their tariff classification, which are provided in the Combined Nomenclature of the EU is different from the descriptions and interpretations of the HSENs, the Court usually applies the rules of the Combined Nomenclature and doesn't provide any explanations on the facts of the discrepancies between the two documents (see for example administrative case UAB "Bottcher Balticum" v Customs Department under the Ministry of Finance of Lithuanian Republic, the Supreme Administrative Court of Lithuania, 9 December 2010 ruling in the administrative case No. A $^{261}$ 1706/2010, 2010).

The situation is further complicated by the fact that there are cases in which the Supreme Administrative Court of Lithuania has ruled that in general in the cases on the tariff classification of 
goods the Court is not entitled to evaluate the provisions of the HSENs in detail. This judicial precedent was at first formulated in 2012, that is in the administrative case UAB "Imlitex" v Customs Department under the Ministry of Finance of Lithuanian Republic (the Supreme Administrative Court of Lithuania, 13 February 2012 ruling in the administrative case No. $A^{261}-218 / 2012,2012$ ) and later repeated in other cases, such as UAB "Plungès kooperatinè prekyba" v Customs Department under the Ministry of Finance of Lithuanian Republic, 2013 (the Supreme Administrative Court of Lithuania, 23 May 2013 ruling of the panel of judges in the administrative case No. $A^{261}-718 / 2013$ ). Thus in the administrative cases which are mentioned above the Supreme Administrative Court of Lithuania based its decisions solely on the provisions of the Combined Nomenclature of the EU which were considered as relevant for the legal relations concerning these particular disputes.

Therefore, although the national courts in principle agrees with the fact that the tariff classification of goods should be based on the provisions of HSENs, but in the specific dispute situations this source of law is not invoked even as an additional, interpretive source for the interpretation of the Combined Nomenclature of EU (as it is done in the practice of the CJEU). This is obviously creating the conditions to distort the EU's Common Commercial Policy and the uniform implementation of the EU's Common Customs Tariff. For example, while refusing to refusing to apply the HSENs the national courts doesn't analyze or even mention the existence of factors, which, according to the already mentioned practice of the CJEU are essential in order to make the decision to refer to the HSENs or not, such as the absence (or non-absence) of the relevant EU legislation on the tariff classification of goods, the existence (or non-existence) of the discretion of WCO to provide the explanations on the classification of specific goods, and, finally, the consistency of the HSENs (with the provisions of the Combined Nomenclature and its headings as well as the chapter or section notes. Although the final decision as to what rules should be applied in the particular dispute on the classification of goods should be taken after an examination of all these aspects, under the Lithuanian judicial practice such examination (investigation) usually is not carried out, even if the applicants raises the related questions in their complaints.

According to the individual Lithuanian authors (Gurevičienè, Sarapinienè 2014) which has examined some aspects of these issues, the problems related to the proper application of the HSENs and other legal sources governing the tariff classification of goods can be explained by the poor accessibility to the legal documents, especially taking into account position of private entities (international trade operators/taxpayers). For example, the relevant version of the HSENs has not been officially translated and published in Lithuania, therefore the information provided in them could be downloaded from the WCO website in foreign languages (this creates additional financial costs as it is not freely available) or accessed by the private persons on the ad hoc basis by making individual requests to the Tariff division of the Customs Department under the Ministry of Finance of Lithuanian Republic, although it is also a lengthy procedure which is unsuitable for business operations (Gurevičiene, Sarapiniene 2014). It is clear that the similar problems are encountered by the state authorities which are examining tax disputes and the courts. Currently, they have the ability to rely only on the documents provided in the specific case and have no practical possibility to analyze the text of the HSENs independently.

Accordingly, in order to ensure the proper application of the HSENs in the Republic of Lithuania and to ensure the uniformity of tariff classification of goods throughout the EU (which is required by the practice and case-law of the CJEU), it is necessary to solve the above-mentioned problems. This requires both the legislative changes, as well as other solutions. First of all, as in the national jurisprudence the HSENs is not always seen as a source of law which must be taken into account in the process of interpretation of the EU customs law, it is necessary to adjust the Article 35 of the Law on Customs of the Republic of Lithuania by implicitly stating that the interpretation of the EU's Combined Nomenclature during the classification process must be based on the provisions of the HSENs. Secondly, the HSENs itself, as a source of law, should be translated into the Lithuanian language and published as a separate publication, since otherwise there remains a risk that the international commitments of Lithuania, as the EU Member State, to implement the Harmonized System Convention will not be secured properly. 
Rules of Origin. Based on the review of the literature, one of the main problems in this area is the allocation of the burden of proof on customs origin of imported goods. Therefore, a key question on the regulation of such issues in Lithuania is how the Lithuanian courts and other competent authorities interpret general legal criteria of customs origin (goods, which are "wholly obtained" in one country, and goods, which underwent substantial transformation in a certain country) in order to define both non-preferential and the preferential status of the goods. According to the Union Customs Code (2013) (Chapter II "Origin of Goods"), goods wholly obtained in a single country are originating in that country and goods whose production involved more than one country are deemed to originate in the country where they underwent their last, substantial transformation. Goods originating in a country are those wholly obtained or produced in that country. When production in more than one country is involved (and that is normally the case), goods are deemed to originate where they underwent their last substantial economically justified processing or working (see case C-373/08 (Hoesch Metals and Alloys GmbH v Hauptzollamt Aachen, 2010)). So, in this respect, the question arises how the burden of proof in determining the origin of goods should be distributed between the importer and the customs authorities? Does the determination of the customs origin, which is completed by the national customs authorities, must always be based on the certificates, provided by country from which the goods were imported and in what cases it has a right to question the legitimacy of the evidence submitted by the importers and its validity and to take into account additional evidence in its sole discretion (ex officio)?

These types of disputes have been settled in cases on the taxation of goods imported from the third countries to the EU (Lithuanian) customs territory in administrative cases of the Lithuanian Supreme Administrative Court UAB "Baltical" v Customs Department under the Ministry of Finance of Lithuanian Republic, 2014 (the Supreme Administrative Court of Lithuania, 30 April 2014 ruling of the panel of judges in the administrative case $\left.A^{261}-146 / 2014,2014\right)$ and UAB "Žalvaris" v Customs Department under the Ministry of Finance of Lithuanian Republic, 2014 (The Supreme Administrative Court of Lithuania, 30 April 2014 ruling of the panel of judges in the administrative case No. $\mathrm{A}^{261}$ $144 / 2014,2014)$. There the courts tried to answer the question whether, according to the general rules of origin, these countries could be considered as the countries of customs origin for the imported goods.

In general, addressing these issues in the practice of the CJEU (see cases Pascoal \& Filhos Ld. v Fazenda Pública, 1997; CAS SpA v Commission, 2008) is based on the assumption that the basic element of the relationship between importing and exporting states in relation to the verification of origin is the system where the origin is being established by the authorities of the exporting country. This is justified by the fact that the authorities of the exporting country are in the position to verify directly the facts, which determine the origin. However, as it was noted by the CJEU, the authorities concerned on both sides must monitor the system jointly and the mechanism of it can function only if the customs authorities of the importing country accept the determinations legally made by the authorities of the exporting country (case C-442/08 (Commission v Germany, 2010, para. 72-73); case C-386/08 (Brita v Hauptzollamt Hamburg-Hafen, 2010, para. 62).

On the other hand, this rule is not absolute, and the practice of the CJEU, as well as the legal doctrine (Lyons 2008, p. 238) confirms that if the customs office has reasonable doubts on the certainty of the certificates of customs origin, it can carry out an additional investigation (post-clearance checks) (case Les Rapides Savoyards v Directeur General des Douanes et Droits Indirects, 1983). A subsequent verification must be carried out not only when the importing Member State so requests, but also, in general, when, there are indications which point to an irregularity in regard to the origin of the imported goods (case C-409/10 (Afasia Knits Deutschland GmbH v Hauptzollamt Hamburg-Hafen, 2011, para. 32), joined cases C-23/04 to C-25/04 (Sfakianakis v Elliniko Dimosio, 2006, para. 30 and 31 ) and case $C^{-442 / 08}$ (Commission v Germany, 2010, para. 82)). When verification shows that a certificate of origin is inaccurate, the importer will be likely, subsequently be faced with a claim for post-clearance recovery of customs duty (see joined cases CT Control (Rotterdam) BV and JCT Benelux BV v Commission, 1993 and case Criminal Proceedings Against Edmond Huygen and others, 1993). The CJEU has also pointed out that in such case, a prudent trader aware of the rules must be able to assess the risks inherent in the market, which he is considering, and accept them as normal 
trade risks (case Amministrazione delle Finanze v Enterprise Ciro Acampora, 1980). However, the practice of the CJEU falls short of defining exact conditions for such verification procedures and the guarantees applicable to importers, although it is noted, that the risks which the traders must take in such cases are not "unlimited" (Kaufring and Others v Commission, 2001).

This gap between legal regulation and practice is essentially filled by the Lithuanian case law in particular type of cases, that is cases where an anti-dumping customs duties were imposed on the goods imported by the economic operator and the imposition of such duties was justified by the fact that the customs origin of these goods matches the particular country to which such duties were applied by the decision of the EU's competent authorities. There the national case law has established the additional guarantees to the importers and obliged the customs authorities to carry out additional investigations of the documents (evidence) and even the nature of economic operations with goods in order to determine their true customs origin. For example, in cases concerning imports of silicon products, which were processed in Taiwan, the Supreme Administrative Court of Lithuania has repeatedly ruled that Lithuanian customs wrongly considered China as the country of their customs origin and had no legal reason to apply anti-dumping customs duties, which were applicable by the EU for such goods, imported from China (the Supreme Administrative Court of Lithuania, 30 April 2014 ruling of the panel of judges in the administrative case $A^{261}-146 / 2014,2014$; the Supreme Administrative Court of Lithuania, 30 April 2014 ruling of the panel of judges in the administrative case No. A $\left.{ }^{261}-144 / 2014,2014\right)$. Thus, the Supreme Administrative Court of Lithuania acknowledged that the duty to prove the customs origin of goods, which are subject to anti-dumping customs duties, must be transferred to the national customs authorities (such conclusion was based on the general rule that the validity of an anti-dumping duty must be proved by the customs). However the national court didn't specify in detail the legal origin or background of this rule merely stating that the duty to prove the customs origin of goods which are subject to an anti-dumping duties should be interpreted as an obligation to prove the connection between the origin of the imported goods and their processing in another country (the customs authorities are obliged to use all means of evidence which are possibly available to them in order to determine the country of origin, which is subject to anti-dumping duties). In order to justify this conclusion in the rulings commented above the Court made only the reference to the Community Customs Code (Council Regulation (EEC) No 2913/92 of 12 October 1992 establishing the Community Customs Code 1992), Article 25. However, the Article 25 of the Community Customs Code only provides a general rule which lays down the operations which do not provide a customs origin and doesn't set any special rules for the application of anti-dumping customs duties.

Besides, as it was additionally noted by the Court, the determination of customs origin itself may not be considered as the tax relief (exemption), the taxpayer is only sufficient to prove the mere existence of business operations, which were useful to him and which has influenced the change of the customs origin. However, as it was also stressed by the Court in the cases cited above, such situation may not be interpreted as a transposition of the burden of proof to the taxpayer as only the obligation to prove the conditions of tax exemption or relief applies to the person seeking such relief or exemption (according to the opinion of the Court, the rules of customs origin according to their nature should not be interpreted as the form of tax relief or exemption). This recent practice of the Supreme Administrative Court of Lithuania raises the importance of two aspects of the process of the determination of customs origin. Firstly, it stresses the fact, that the decisions of the national customs authorities on the determination of customs origin should be based not only on the formal sources of evidence but on the ascertaining of the real content of business transactions (such the processes of production and subsequent further processing of goods). Secondly, it substantially restricts the conditions for the application of anti-dumping customs duties in Lithuania on goods imported from the third countries to which such duties are applied by the EU and in general is more focused on the protection of the rights and interests of taxpayers (importers of goods) than on the protection of the fiscal interests of the EU and the Member State. This raises the subsequent question whether such practice, in general, is consistent with the position of the CJEU, especially as the national court haven't provided any arguments for the legal origin of the principle that the validity or legality of an antidumping customs duty must proved by the customs authorities themselves. 
It should be emphasized that, as was pointed out before, there is an absence of the consistent practice of the CJEU on this particular matter (on the distribution of the burden of proof on the origin of goods, to which an anti-dumping customs duties are applied). On the other hand, the latest practice of the General Court of EU, which has recently started to be formed in case T-412/13 (Chin Haur Indonesia, PT v Council, 2015, para. 118), leads to the conclusion that the primary obligation to provide an evidence on the origin of imported goods should be switched to the importer: the information submitted by the applicant (importer) should be sufficient to determine whether the applicant hadn't participated in circumvention of the anti-dumping duties. Hence, in this regard, Lithuanian national judicial practice and the position of the EU judicial authorities do not match, therefore, such situation raises the question about the necessity to review certain provisions of national law on the rules of origin of imported goods (Law on Customs of the Republic of Lithuania, 2004). In particular, it may seem relevant to add certain provisions on the distribution of the burden of proof between the taxpayer (importer) and customs authorities (currently such regulations are completely absent in text of the national law), imperatively emphasizing that the primary responsibility for proving the customs origin of goods belongs to the importer (Articles 37-38 of the Law on Customs of the Republic of Lithuania).

Customs Valuation. In deciding the question whether the WTO rules on customs valuation may be applied directly to the system of the EU law, CJEU has repeatedly pointed out that individual rules of the WTO Agreements do not have characteristics, which are necessary to consider them to be directly applied (self-executing) (case C-361/11 (Rechtbank Haarlem v Inspecteur van de Belastingdienst/Douane West, kantoor Hoofddorp, 2013, para. 57); case C-306/13 (LVP NV v Belgische Staat, 2014)). Therefore, an importer or exporter shall be entitled to rely on the WTO rules only when the EU institution intended to implement a particular obligation assumed under the GATT Agreement by means of the EU legislation or when the EU legislation provides a clear reference to the legal provisions of the WTO (GATT) agreements. In the practice of the CJEU, such examples are applied in the field of anti-dumping customs duties, but not in the determination of customs valuation.

However the national courts in Lithuania applies WTO rules on customs valuation not only in the specific cases (for example when there are no clear EU rules on customs valuation), but also in defining the general duties of persons, participating in international trade operations, despite the fact that procedures of valuation of goods for customs procedures are regulated in detail by the Community Customs Code (Article 29). Such practice was followed by the Supreme Administrative Court of Lithuania in the administrative case UAB „Matroksas" v Customs Department under the Ministry of Finance of Lithuanian Republic (The Supreme Administrative Court of Lithuania, 5 May 2010 ruling of the panel of judges in the administrative case No. $\left.A^{442}-715 / 2010,2010\right)$ and in the administrative case "Editos Šakytès įmonè" v Customs Department under the Ministry of Finance of Lithuanian Republic (The Supreme Administrative Court of Lithuania, 2 November 2010 ruling of the panel of judges in the administrative case No. $\left.A^{143}-1243 / 2010,2010\right)$. Here, the court has pointed out that has pointed out that under the WTO rules in cases where the customs authorities have a reasonable doubt on the declared value of the goods and accuracy of the customs value, the burden of proof is shifted to the importer.

Consequently, the interpretation of rules, applied to the customs valuation, differs both at the level of the CJEU practice and at the level of the national practice. As a possible solution to this problem, we may indicate the necessity to review the provisions of the EU law itself that is Article 2, para. 1 of the Community Customs Code, which should include clarifications on the relationship between EU customs law and international agreements, distinguishing the agreements that can't be applied directly.

\section{Conclusions}

From the perspective of certain EU Member States (i.e. Lithuania), the uniform implementation of Common Commercial Policy and the Common Customs Tariff, as its main element, is not fully ensured on the practical level. The research highlights that significant differences between national practices and practices for the application of relevant EU customs law, which is formed by the CJEU, were detected. 
Although the national courts in Lithuania in principle agrees with the fact that the tariff classification of goods should be based on the provisions of HSENs, but in the specific dispute situations this source of law is not invoked even as an additional, interpretive source for the interpretation of the Combined Nomenclature of EU (as it is done in the practice of the CJEU). According to the CJEUit, the scope and the purpose of the application of the HSENs is to explain the existing sources of the EU law, such as the Combined Nomenclature and the HSENs itself could be treated as directly applicable in some exceptional cases (when there are no relevant EU law which regulates tariff classification of specific goods). Although the final decision as to what rules should be applied in the particular dispute on the classification of goods should be taken after an examination of all these aspects, under the Lithuanian judicial practice such examination (investigation) usually is not carried out, even if the applicants raises the related questions in their complaints. This signal the need for the legislative review of the rules, entrenched in the Law on Customs of the Republic of Lithuania (2004), in particular, the Article 35 , para. 1, that should implicitly define the application of the HSENs and to provide legal guarantees for the proper accessibility to this source of law in Lithuania.

Lithuanian national judicial practice and the position of the EU judicial authorities do not match in cases on the determination of customs origin of imported goods, in particular in cases when the burden of proof of customs origin is transferred to the customs authorities, and not to the importer. Therefore, such situation raises the question about the necessity to review certain provisions of national law on the rules of origin of imported goods, imperatively emphasizing that the primary responsibility for proving the customs origin of goods belongs to the importer (Articles 37-38 of the Law on Customs of the Republic of Lithuania).

Consequently, the interpretation of rules, applied to the customs valuation, differs both at the level of the CJEU practice and at the level of the national practice, which allows direct application of the WTO Agreements in the national legal system (what is not recognized by the practice of the CJEU). As a possible solution to this problem, we may indicate the necessity to review the provisions of the EU law itself that is Article 1, para. 1 of the Union Customs Code, which should include clarifications on the relationship between EU customs law and international agreements, distinguishing the agreements that can't be applied directly.

\section{References}

Audet, D. (2007). Smooth as Silk? A First Look at the Post MFA Textiles and Clothing Landscape. Journal of International Economic Law, 10(2), 267-284.

Barnard, C. (2010). The substantive law of the EU: the four freedoms. Oxford: Oxford University Press.

Baronaitè, M. (2010). Naudoty apgadintu transporto priemoniu muitinio vertinimo ypatumai [Peculiarities of the customs valuation of used and damaged transport vehicles]. Teisé, 77, 63-80.

Broberg, M. (2011). What Is the Direction for the EU's Development Cooperation after Lisbon? European Foreign Affairs Review 16, 539-557.

Case C-291/11 TNT Freight Management (Amsterdam) v Staatssecretaris van Financiën, 2012 EU:C:2012:459.

Case 14/70 Deutche Bakels GmbH v Oberfinanzdirektion Munchen, 1970 E.C.R. 1001.

Case 248/80 Kommanditgesellschaft in Firma Gebrüder Glunz v Hauptzollamt Hamburg-Waltershof, 1982 E.C.R. 00197.

Case 38-75 Douaneagent der NV Nederlandse Spoorwegen v Inspecteur der invoerrechten en accijnzen, 1975 E.C.R. 01439.

Case 77/71 Gervais-Danone AG v Hauptzollamt Munchen-Schwanthalerstrasse [1971] E.C.R. 1127.

Case 827/79 Amministrazione delle Finanze v Enterprise Ciro Acampora, 1980 E.C.R. 03731.

Case 8/73 Hauptzollamt Bremerhaven v Massey-Ferguson GmbH, 1973 E.C.R. 00897.

Case 11/79 J. Cleton en Co. BV v Inspecteur des droits d'entrée et accises a Rotterdam, 1979 E.C.R. 03069.

Case C-134/13_Raytek GmbH and Fluke Europe BV v Commissioners for Her Majesty's Revenue and Customs, 2015 EU:C:2015:82. 
Case C-178/14 Vario Tek v Hauptzollamt Düsseldorf, 2015 EU:C:2015:152.

Case C-196/10 Paderborner Brauerei Haus Cramer KG v Hauptzollamt Bielefeld, 2011 E.C.R. I-06201.

Case C-204/07 CAS SpA v Commission, 2009 E.C.R. I-00140.

Case C-206/03 Commissioners of Customs \& Excise v SmithKline Beecham plc, 2005 E.C.R. I-00415.

Case C-208 and 209/06 Medion AG v Hauptzollamt Duisburg and Canon Deutschland GmbH v Hauptzollamt Krefeld, 2007 E.C.R. I-07963.

Case C-218/83 Les Rapides Savoyards Sàrl and others v Directeur Général des Douanes et Droits Indirects, 1984 E.C.R. 03105 .

Case C-229/06 Sunshine Deutschland Handelsgesellschaft v Hauptzollamt Kiel, 2007 E.C.R. I-03251.

Case C-233/88 Gijs van de Kolk - Douane Expéditeur BV v Inspecteur der Invoerrechten en. Accijnzen, 1990 E.C.R I-265.

Case C-267/13 Nutricia NV v Staatssecretaris van Financiën, 2014 EU:C:2014:277.

Case C-297/13 Data I/O v Hauptzollamt München, 2014 EU:C:2014:331.

Case C-306/13 LVP NV v Belgische Staat, 2014 EU:C:2014:2465.

Case C-312/07 JVC France v Administration des douanes - Direction nationale du renseignement et des enquêtes douanières, 2008 E.C.R. I-04165.

Case C-361/11 Hewlett-Packard Europe BV v Inspecteur van de Belastingdienst/Douane West, kantoor Hoofddorp, 2013 EU:C:2013:18.

Case C-361/11 Rechtbank Haarlem v v Inspecteur van de Belastingdienst/Douane West, kantoor Hoofddorp, 2013 EU:C:2013:18.

Case C-373/08 Hoesch Metals and Alloys GmbH v Hauptzollamt Aachen, 2010 E.C.R. I-00951.

Case C-38/75 Douneagent der NV Nederlandse Sooprwegen v Inspecteur der Invoerrechten en Accijinzen, 1975 E.C.R 1439.

Case C-386/08 Brita v Hauptzollamt Hamburg-Hafen, 2010 E.C.R.I-1289.

Case C-396/02 DFDS BV v Inspecteur der Belastingdienst — Douanedistrict Rotterdam, 2004 E.C.R. I-08439.

Case C-409/10 Afasia Knits Deutschland GmbH v Hauptzollamt Hamburg-Hafen, 2011 E.C.R. I-13331.

Case C-42/99 Fábrica de Queijo Eru Portuguesa Ld ${ }^{a}$ v Tribunal Técnico Aduaneiro de Segunda Instância, 2000 I-07691.

Case C-44/15 Duval v Hauptzollamt Frankfurt am Main, 2015 EU:C:2015:783.

Case C-442/08 Commission v Germany, 2010 E.C.R. I-0000.

Case C-472/12 Panasonic Italia SpA, Panasonic Marketing Europe GmbH, Scerni Logistics Srl v Agenzia delle Dogane di Milano, 2014 EU:C:2014:2082.

Case C-97/95 Pascoal \& Filhos Ld. v Fazenda Pública, 1997 E.C.R. I-04209.

Case T-412/13 Chin Haur Indonesia, PT v Council of the European Union, 2015 EU:T:2015:163.

Commission Regulation No. 1101948/200914 on the tariff and statistical nomenclature and on the Common Customs Tariff (200915). Official Journal, L 287285.

Council Regulation (EEC) No 2913/92 of 12 October 1992 establishing the Community Customs Code (1992). Official Journal, L302.

Craig, P., de Burca, G. (2011). The Evolution of the EU Law. Oxford: Oxford University Press.

Devuyst, T. (2011). The European Union's Competence in International Trade after the Treaty of Lisbon. The Georgia Journal of International and Comparative Law, 39, 640-660.

Eechaut, P. (2011). EU External Relations Law. Oxford: Oxford University Press.

Einhorn, T. (2012). Customs Law, International. The Max Planck Encyclopedia of Public International Law, Volume II. Oxford: Oxford University Press, 961-962. 
Gurevičienè, J., Sarapinienè, S. (2014). Muitinès formalumai tarptautinejje prekyboje [Customs formalities in the international trade]. From Muitine tarptautinès prekybos logistineje grandineje [Customs in the International Trade Logistical Chain] (eds. A. Laurinavičius, J. Gurevičienė, A. Jablonskis). Vilnius: Mykolo Romerio universitetas, 108-210.

Herdegen, M. (2013). Principles of International Economic Law. Oxford: Oxford University Press.

Joined cases 21 to 24-72 International Fruit Company NV and others v Produktschap voor Groenten en Fruit, 1972 EU:C:1972:115.

Joined cases 267/81, 268/81 and 269/81 SPI and SAMI v Amministrazione delle Finanze dello Stato, 1983 E.C.R. 00801.

Joined cases C-121/91 and C-122/91 CT Control (Rotterdam) BV and JCT Benelux BV v Commission, 1993 E.C.R. I-03873.

Joined cases C-23/04 to C-25/04 Sfakianakis v Elliniko Dimosio, 2006 E.C.R. I-1265.

Joined Cases C-288/09 British Sky Broadcasting Group plc v The Commissioners for Her Majesty's Revenue \& Customs and C-289/09 Pace plc v The Commissioners for Her Majesty's Revenue \& Customs, 2011 E.C.R. I02851 .

Joined cases C-522/07 and C-65/08 Dinter GmbH v Hauptzollamt Düsseldorf and Europol Frost-Food v Hauptzollamt Krefeld , 2009 E.C.R. I-10333.

Joined cases T-186/97, T-187/97, T-190/97 to T-192/97, T-210/97, T-211/97, T-216/97, T-217/97, T-218/97, T279/97, T-280/97, T-293/97 and T-147/99 Kaufring and Others v Commission, 2001 E.C.R. II-01337.

Law of the Republic of Lithuania on the ratification of Agreement founding World Trade Organization and its Annexes (2001). Official Gazette, 46 (1620).

Law of the Republic of Lithuania on the ratification of Harmonized Commodity Description and Coding System Convention (2001). Official Gazette, 61 (2772).

Law on Customs of the Republic of Lithuania (2004). Official Gazette, 73 (2517).

Leal-Arcas, R. (2008). Theory and Practice of EC External Trade Law and Policy. London: Cameron May.

Leal-Arcas, R. (2010). The European Union's Trade and Investment Policy after the Treaty of Lisbon. The Journal of World Investment and Trade. (11), 463-514.

Leal-Arcas, R. (2011). International Trade and Investment Law. Multilateral, Regional and Bilateral Governance. Cheltenham, UK: Edward Elgar Publishing Ltd.

Limbach, K. (2015). Uniformity of Customs Administration in the European Union. Oxford: Hart Publishing.

Lux, M. (2002). Guide to Community Customs Legislation. Bruxelles: Bruylant.

Lux, M. (2007). EU Customs Law and International Law. World Customs Journal, 1(1), 19-29.

Lyons, T. (2008). EC Customs law. Oxford: Oxford University Press.

Moussis, N. (2015). Access to European Union: law, economics, policies. Cambridge: Intersentia Limited.

Radžiukynas, J., Belzus, A. (2008). Importuojamu prekiu muitinis juvertinimas ir kontrole [Customs Valuation of Imported Goods and its Control]. Vilnius: Lietuvos prekybos, pramonès ir amatų rūmų asociacija.

Radžiukynas, J., et al. (2011). Europos Sajungos Bendroji Prekybos Politika [The Common Commercial Policy of the EU]. Vilnius: Mykolo Romerio universitetas.

Regulation (EU) No 952/2013 of the European Parliament and of the Council of 9 October 2013 laying down the Union Customs Code (2013). Official Journal, L 269.

Rovetta, D. (2010). Are Tariff Explanatory Notes Subject to Judicial Supremacy? Global Trade and Customs Journal, 5(3), 129-132.

Rovetta, D. (2010). Are Tariff Explanatory Notes Subject to Judicial Supremacy? Global Trade and Customs Journal, 5(3), 129-132.

Terra, B. J. M., Wattel, P. J. (2012). European Tax Law. The Hague: Kluwer Law International.

Terra, B. J. M., Wattel, P. J. (2012). European Tax Law. The Hague: Kluwer Law International. 
The Supreme Administrative Court of Lithuania 1 February 2011 ruling of the panel of judges in the administrative case No. $\mathrm{A}^{143}-218 / 2011$. Access through the Internet: < http://liteko.teismai.lt/ viesasprendimupaieska/tekstas.aspx?id=750ebcbc-c579-49c3-831a-73ea93dec19d $>$.

The Supreme Administrative Court of Lithuania 28 January 2010 ruling of the panel of judges in the administrative case No. $\mathrm{A}^{442}-176 / 2010$. Access through the Internet: < http://liteko.teismai.lt/ viesasprendimupaieska/tekstas.aspx?id=b47d4096-f6cf-480f-98d2-ba32df285be2>.

The Supreme Administrative Court of Lithuania, 13 February 2012 ruling in the administrative case No. A ${ }^{261}$. 218/2012. Access through the Internet: <http://liteko.teismai.lt/viesasprendimupaieska/ tekstas.aspx?id=750ebcbc-c579-49c3-831a-73ea93dec19d $>$.

The Supreme Administrative Court of Lithuania, 2 November 2010 ruling of the panel of judges in the administrative case No. $\mathrm{A}^{143}-1243 / 2010$. Access through the Internet: <http://liteko.teismai.lt/ viesasprendimupaieska/tekstas.aspx?id=82ab5a89-39e9-4d19-a7ad-e591b109423a>.

The Supreme Administrative Court of Lithuania, 21 February 2013 ruling of the panel of judges in the administrative case No. $A^{442}-165 / 2013$. Access through the Internet: < http://liteko.teismai.lt/viesasprendimupaieska/tekstas.aspx?id=87381193-fe65-4901-b600-bfc582165fe4>.

The Supreme Administrative Court of Lithuania, 23 May 2013 ruling of the panel of judges in the administrative case No. $\mathrm{A}^{261}-718 / 2013$. Access through the Internet: <http://liteko.teismai.lt/ viesasprendimupaieska/tekstas.aspx?id=05af17e3-37cc-4d31-a022-be9ee7adb2a2>.

The Supreme Administrative Court of Lithuania, 3 February 2012 ruling of the panel of judges in the administrative case No. $\mathrm{A}^{575}-1388 / 2012$. Access through the Internet: $<$ http://liteko.teismai.lt/viesasprendimupaieska/tekstas.aspx?id=29e31627-d054-4718-86ef-487d908e6622>.

The Supreme Administrative Court of Lithuania, 30 April 2014 ruling of the panel of judges in the administrative case $\mathrm{A}^{261}-146 / 2014$. Access through the Internet: < http://liteko.teismai.lt/ viesasprendimupaieska/tekstas.aspx?id=7fed64e2-d0fd-4a7b-aa04-4eb9217e9394>.

The Supreme Administrative Court of Lithuania, 30 April 2014 ruling of the panel of judges in the administrative case No. $\mathrm{A}^{261}-144 / 2014$. Access through the Internet: <http://liteko.teismai.lt/ viesasprendimupaieska /tekstas.aspx?id=bd0247d2-356e-4884-af9b-4e13af675f67>.

The Supreme Administrative Court of Lithuania, 31 January 2013 ruling of the panel of judges in the administrative case No. $\mathrm{A}^{143}-71 / 2013$. Access through the Internet: <http://liteko.teismai.lt/ viesasprendimupaieska/tekstas.aspx?id=d6a613ef-ca3b-4d54-b33f-5f99fce90b90>.

The Supreme Administrative Court of Lithuania, 4 October 2010 ruling of the panel of judges in the administrative case No. A $\mathrm{A}^{261}-1408 / 2010$. Access through the Internet: < http://liteko.teismai.lt/viesasprendimupaieska/tekstas.aspx?id=18145025-3b18-4a83-9c9a-db2bdffc974d>.

The Supreme Administrative Court of Lithuania, 5 May 2010 ruling of the panel of judges in the administrative case No. $A^{442}-715 / 2010$. Access through the Internet: <http://liteko.teismai.lt/viesasprendimupaieska/ tekstas.aspx?id=cf2380b1-bfba-42de-b979-3ab206141800>.

The Supreme Administrative Court of Lithuania, 7 October 2013 ruling in the administrative case No. $A^{442}$ 1156/2013. Access through the Internet: <http://liteko.teismai.lt/ viesasprendimupaieska/tekstas. aspx?id=451 f440f-9eb4-4c04-be4e-f6dacea4c856>.

The Supreme Administrative Court of Lithuania, 9 December 2010 ruling in the administrative case No. $\mathrm{A}^{261}$ 1706/2010. Access through the Internet: <http://liteko.teismai.lt/viesasprendimupaieska/tekstas.aspx?id $=\mathrm{e} 1 \mathrm{c} 5 \mathrm{a} 1 \mathrm{fe}-9883-49 \mathrm{e} 1-\mathrm{b} 313-04 \mathrm{~b} 92 \mathrm{~b} 9 \mathrm{~d} 8 \mathrm{f} 11>$.

Treaty on the Functioning of the European Union (2012). Official Journal, C 326.

Weerth, C. (2008). HS 2007: Notes of the Tariff Nomenclature and the Additional Notes of the EC. World Customs Journal. 2(1), 111-115.

Wolffgang H. M., Ovie, T. (2008). Emerging Issues in European Customs Law - Part 3. World Customs Journal, 2(1), 3-17.

Wolffgang, H. M., Kafeero, E. (2014). Legal thoughts on how to merge trade facilitation and safety \& security. World Customs Journal, 8(1), 3-16.

Woolcook, S. (2008). The potential impact of the Lisbon Treaty on European Union External Trade Policy. Stockholm: Swedish Institute for European Policy Studies. 